\title{
In Silico Study: Potential Prediction of Curcuma longa And Cymbopogon citratus Essential Oil As Lipoxygenase Inhibitor
}

\author{
Yohanes Bare $^{1 *}$, Lilin Ika Nur Indahsari ${ }^{2}$, Dewi Ratih Tirto Sari ${ }^{3,4}$, Theopilus Watuguly ${ }^{5}$ \\ ${ }^{1}$ Biology Education Study Program, Faculty of Teacher and Training Education, Nusa Nipa University, Jl. Kesehatan \\ No 03, Sikka, NTT, Indonesia 86113 \\ ${ }^{2}$ Biology Education Study Program, State Islamic Institute of Palangkaraya, J1. G.Obos Komplek Islamic Center , \\ Palangkaraya, Kalimantan Tengah, Indonesia 73112 \\ ${ }^{3}$ Research Center for Smart Molecules and Natural Genetic Resources, Brawijaya University, Jl. Veteran, Malang, \\ Jawa Timur, Indonesia 65145 \\ ${ }^{4}$ Department of Biology, Faculty of Mathematic and Natural Science, Brawijaya University, Jl. Veteran, Malang, Jawa \\ Timur, Indonesia 65145 \\ ${ }^{5}$ Department of Biology Education, Faculty of Teacher and Training Education, Pattimura University, Jl. Ir. M. \\ Putuhena, Kampus Poka-Ambon Maluku
}

Submission: January 2021; Revised: January 2021; Accepted: March 2021

*Corresponding author: Yohanes Bare; e-mail: bareyohanes@gmail.com; tel.: +6285337373969

\begin{abstract}
Inflammation is the human body response when pathogens enter and attack the immune system. One of the effects of inflammation is the activation of the Lipoxygenase (LOX) gene. The bioactive from essential oil such as Curcuma longa and Cymbopogon citratus that has potential pharmacologist activity can be used to curve the inflammation. This research aimed to investigate the role of Curcuma longa and Cymbopogon citratus essential oil through the LOX gene activity. The study adapted by in silico study. Several chemical substances, including 3,7dimethyl-1,3,6-octatriene, camphor, eugenol, curzerenem, and isoborneol, were retrieved from the PubChem database. The PyRx 0.8 was used to minimize and convert the sdf file to a pdb format file of ligands. Those compounds were predicted their interaction using STITCH online server. Ligands and protein were docked by HEX Cuda 8.0.0 program, $3 D$ and $2 D$ views were evaluated using Discovery studio ver.19.0.0 and LigPlot+ ver 2.2, respectively. We found fourteen amino acid residues from LOX which bound the chemical compounds. A hydrogen bond supported those interactions with a variety of energy binding. To sum up, the essential oil from Curcuma longa and Cymbopogon citratus has a potential function as inhibitor LOX by inhibiting fourteen active sides of the LOX gene.
\end{abstract}

Keywords: Curcuma longa, Cymbopogon citratus, essential oil, inflammation, lypoxygenase

\section{INTRODUCTION}

The herbal essential oil has become a popular product for relaxation. Several plants were used to produce the essential oil, such as Pogostemon cablin, lemongrass, geranium, orchids, rose, and rosemary. Every essential oil has specific functions. Lemongrass or Cymbopogon citratus has been reported to contain some bioactive substances, such as alkaloids, flavonoids, steroid, and terpenoids. Bioactive compounds in lemongrass essential oil are geraniol, citral, citronellal, and citronellol [1-4]. Those compounds have functioned as antifungal, antioxidant, anti-inflammation, antidiabetic, antimicrobial, and anti-tumor [5-10].

Turmeric or Curcuma longa is an herbal medicine used in the community containing active compounds such as alkaloids, flavonoids, tannins, and phytosterols [11-12]. Turmeric's flavonoid and alkaloid compounds are widely explored for various treatments for anti-cancer, antimicrobial, antioxidant, and antimutagenic properties (11-14). Curcuma oil has been proved to have an antiinflammatory effect in some experimental conditions [14]. Both $C$. citratus and $C$. longa have been known as therapeutic medicine, while the study on this function in the inflammation process is still limited.

Inflammation is a condition in the body characterized by the appearance of proinflammatory signals. During the inflammation, the body will produce a different protein with a specific function [15]. One of the genes which play a role in inflammation condition is lipoxygenase gene (LOX). LOX will affect the human body when inflammation occured and leads to chronic inflammation. The LOX pathway that works during the process is leukotrienes and hydroperoxy fatty acids $[16,17]$. Nowadays, LOX has become a target for inflammatory therapy [18]. The previous study showed LOX as an anticancer [19]. There are pharmacological inhibitors of lipoxygenases (LOX) used because of their ability to decrease some of the cellular and tissue level effects of the inflammatory reaction [20]. In this study, the reduction of inflammatory reactions in the body was conducted by inhibiting LOX as an inflammatory mediator involved during the inflammatory process. Plant derivatives were used 
therapy from secondary metabolites such as phenolic acids to reduce the toxicity of the drugs (20)-(21). We analyzed the potential of the $C$. longa and $C$. citratus essential oils as LOX inhibitors.

\section{METHODS}

\section{Sample preparation and molecular modeling}

Several chemical substances, including 3,7dimethyl-1,3,6-octatriene, camphor, eugenol, curzerene, and isoborneol, were retrieved from the PubChem database with accession number CID5281553, CID2537, CID3314, CID572766, and CID64685, respectively. The PyRx 0.8 was used to minimize and convert the sdf file to $\mathrm{a} \mathrm{pdb}$ format file of ligands. Those compounds' interaction was predicted using STITCH online server and resulted from LOX as a targeted protein. Ligands and protein were docked by HEX Cuda 8.0.0 program, 3D and 2D views were evaluated using Discovery studio ver.19.0.0 and LigPlot+ ver 2.2, respectively.

\section{RESULTS AND DISCUSSIONS}

Interaction of 3,7-dimethyl-1,3,6-octatriene bioactive compound with LOX formed energy binding around $-199.0 \mathrm{~kJ} / \mathrm{mol}$. That interaction showed one amino acid residue binds to the 3,7dimethyl-1,3,6-octatriene in LEU153 of LOX? (Figure 1 and Table 1). However, Camphor and LOX's interaction revealed five amino acid residues that binding to the bioactive compound. The amino acid residues are GLU250, CYS248, PRO252, LYS521, and THR249, with energy binding $-156.3 \mathrm{~kJ} / \mathrm{mol}$ (Figure 1 and Table 1). The bioactive Eugenol and protein LOX were docked and showed energy binding about $-196.7 \mathrm{~kJ} / \mathrm{mol}$. Those interactions reported four amino acid residues (ARG370, PHE450, PHE544, VAL243), bound with the eugenol (Figure 1 and Table 1). The Curzerene showed activity as a LOX inhibitor, which provided binding energy $227.4 \mathrm{~kJ} / \mathrm{mol}$. The potential inhibitor of curzerene showed to inhibit the active site of LOX in amino acid residues ASP333, GLY332, ILE330, LEU153, TRP144 (Figure 1 and Table 1). Isoborneol-LOX complex demonstrated an amino acid residue that was ILE330 with the energy binding of $-153.0 \mathrm{~kJ} / \mathrm{mol}$ (Figure 1 and Table 1).

The visualization of complex binding suggested that complex binding of ligands and LOX provides efficient inhibition. The hydrophobicity level of essential oil-LOX complexes presented differently from other complexes. Camphor and eugenol showed low levels because most of the ligand surface appears light blue towards dark blue. The 3,7-dimethyl1,3,6-octatriene, curzerene, and isoborneol released high levels of hydrophobicity with brown color on the surface.

Throughout the acute inflammatory response, the arachidonic acid (AA) pathway produces proinflammatory in neurodegenerative diseases, this AA pathway has become chronically hyperactivated. According to previous studies, the key regulatory enzymes in the eicosanoid pathway, i.e. 5-LOX and 5-, 12-, and 15-LOX, appear to have an important role in mediating the proinflammatory responses [23]. 5-LOX is a dioxygenase that has a function to convert Arachidonic acid to 5-(S)-hydroperoxyeicosatetraenoic acid [22]. It means the LOX gene contributed to lead inflammation. The analysis shows that various binding sites prove that the raw materials are more effective than consumption only. Arachidonic acid is produced by membrane phospholipids part in the main pathway of pain and inflammation. Arachidonic acid was further metabolized by lipoxygenase and cyclooxygenase pathways. In lipoxygenase, 5-LOX produces leukotrienes, which play a major role in inflammation, gastrointestinal tract (GI) damage, and the primary disease. One of the leukotrienes is converted into lipoprotein A4 by 15-LOX, resolved inflammation conditions, and it has antitumor activity [22-24].

Inhibition the LOX carried out by essential oils from Curcuma longa and Cymbopogon citratus occurs on the active site of the LOX gene in fourteen amino acid residues (LEU153, GLU250, CYS248, PRO252, LYS521, THR249, ARG370, PHE450, PHE544, VAL243, ASP333, GLY332, ILE330, and TRP144) by in silico study. This inhibition will affect the inflammatory process in the human body. It can block various LOX parts and prevent natural arachidonic acid as the original substrate. The inhibition starts by inhibiting lipoxygenase catalyze through inhibiting hydroperoxy eicosatetraenoic acids (HPETEs) from arachidonic acid. Then the HPETEs decreased and converted into eicosanoid, a signal molecule and plays an essential regulatory role in immune reactions and other physiological processes. Generally, lipoxygenase has the ability to oxygenate fatty acids at specific positions [24].

Hydrogen bonds was also reported to promote ligand binding affinities with the proteins and stabilize it (25-29). The combination of phytochemical components will play a synergistic mechanism and improving the human system's biological activity [30-34]. 
1. 3,7-dimethyl-1,3,6-octatriene- LOX

A

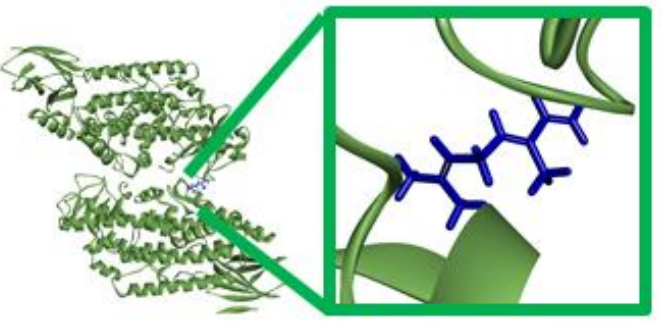

2. Camphor-LOX

A

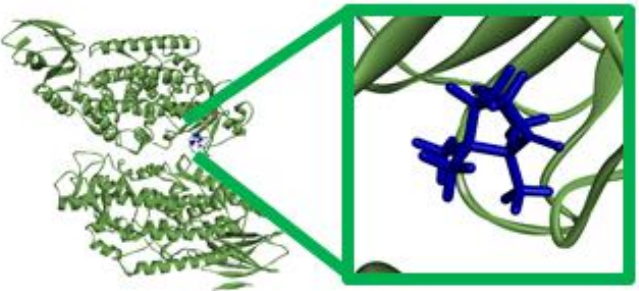

3. Eugenol-LOX

A

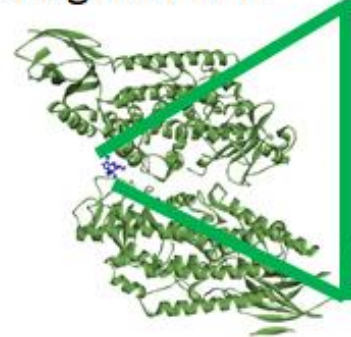

4, Curzerene- LOX

A

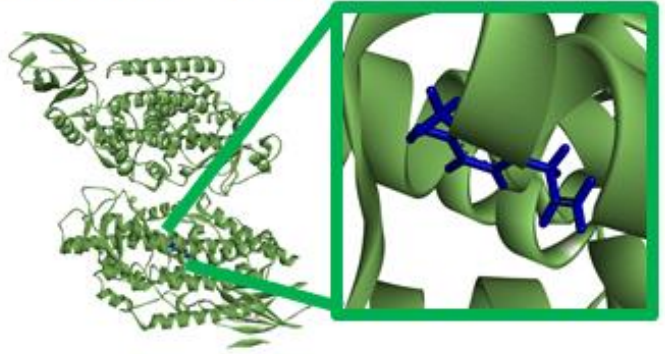

5. Isoborneol- LOX

A

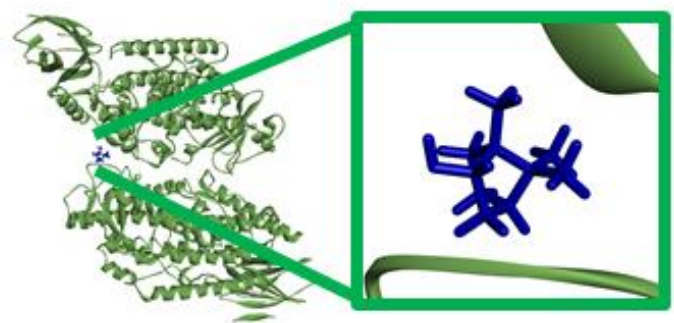

B

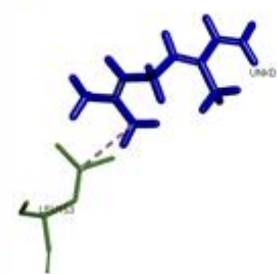

C

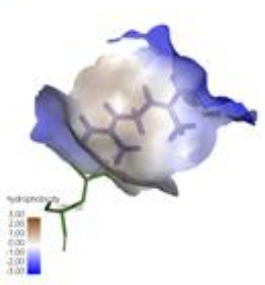

D

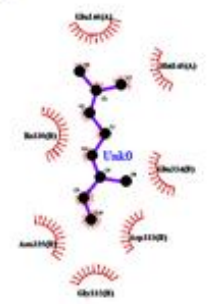

B

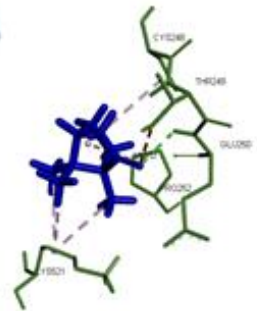

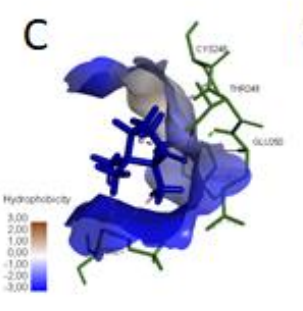

$\mathrm{D}$

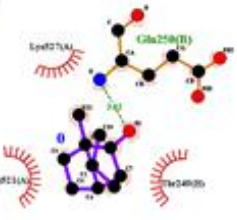

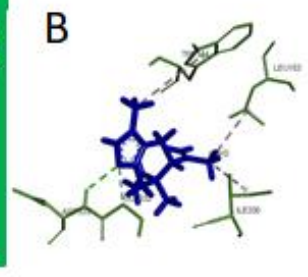
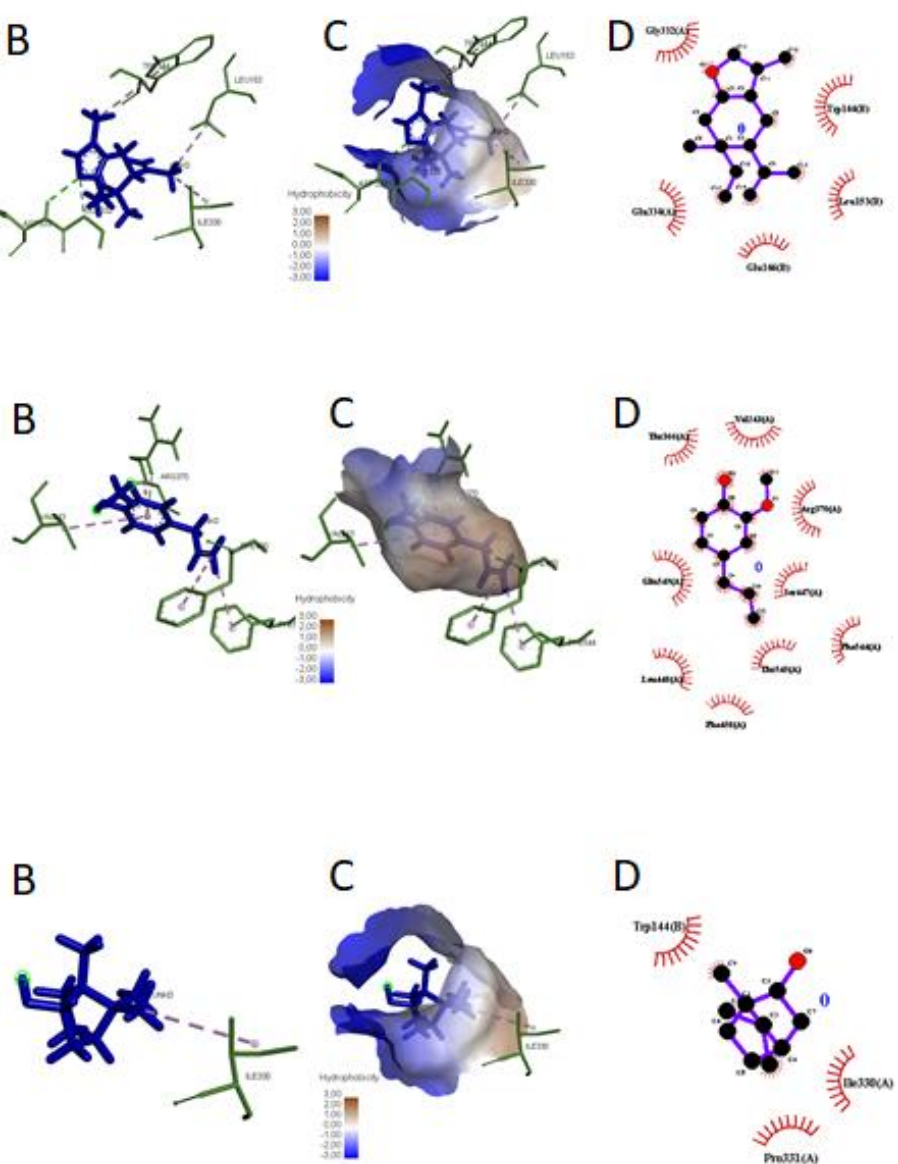

Figure 1. The binding pose of Curcuma longa and Cymbopogon citratus essential oil with lipoxygenase protein, A. The 3D model of the ligand-protein complex, B. Interaction sites of ligand-protein complex, C. Hydrophobicity levels, D. The 2D view of the ligand-protein complex. 
Yohanes B, Lilin INI, Dewi RTS, Theopilus W - In silico study: Prediction potential Curcuma longa

Table 1. Interaction essential oil of Curcuma longa and Cymbopogon citratus through lipoxydase protein

\begin{tabular}{|c|c|c|c|c|c|}
\hline $\begin{array}{l}\text { Ligand-Protein } \\
\text { Complex }\end{array}$ & $\begin{array}{l}\text { Binding energy } \\
(\mathrm{kJ} / \mathrm{mol})\end{array}$ & Interaction & Distance & Category & Type \\
\hline $\begin{array}{l}\text { 1. 3,7-dimethyl- } \\
\text { 1,3,6-octatriene - } \\
\text { LOX }\end{array}$ & -199.0 & : UNK0:C7 - A: LEU153 & 4.86 & Hydrophobic & Alkyl \\
\hline \multirow{7}{*}{ 2. Camphor-LOX } & \multirow{7}{*}{-156.3} & B:GLU250:HN - :UNK0:O1 & 2.44 & Hydrogen Bond & $\begin{array}{l}\text { Conventional Hydrogen } \\
\text { Bond }\end{array}$ \\
\hline & & B:CYS248 - :UNK0 & 5.33 & Hydrophobic & Alkyl \\
\hline & & B:PRO252 - :UNK0 & 5.49 & Hydrophobic & Alkyl \\
\hline & & :UNK0:C9 - A:LYS521 & 3.98 & Hydrophobic & Alkyl \\
\hline & & :UNK0:C10 - A:LYS521 & 3.91 & Hydrophobic & Alkyl \\
\hline & & :UNK0:C11 - A:LYS521 & 3.78 & Hydrophobic & Alkyl \\
\hline & & $\begin{array}{l}\text { B:THR249:OG1 - } \\
\text { :UNK0:O1 }\end{array}$ & 2.92 & Unfavorable & $\begin{array}{l}\text { Unfavorable Acceptor- } \\
\text { Acceptor }\end{array}$ \\
\hline \multirow{5}{*}{ 3. Eugenol-LOX } & \multirow{5}{*}{-196.7} & A:ARG370:HE - :UNK0 & 2.66 & Hydrogen Bond & $\begin{array}{l}\text { Pi-Donor Hydrogen } \\
\text { Bond }\end{array}$ \\
\hline & & A:PHE450 - :UNK0:C12 & 5.07 & Hydrophobic & Pi-Alkyl \\
\hline & & A:PHE544 - :UNK0:C12 & 4.24 & Hydrophobic & Pi-Alkyl \\
\hline & & :UNK0 - A:VAL243 & 5.19 & Hydrophobic & Pi-Alkyl \\
\hline & & :UNK0 - A:ARG370 & 4.70 & Hydrophobic & Pi-Alkyl \\
\hline \multirow{5}{*}{ 4. Curzerene- LOX } & \multirow{5}{*}{-227.4} & A:ASP333:HN - :UNK0:O1 & 2.74 & Hydrogen Bond & $\begin{array}{l}\text { Conventional Hydrogen } \\
\text { Bond }\end{array}$ \\
\hline & & A:GLY332:CA - :UNK0:O1 & 3.17 & Hydrogen Bond & Carbon Hydrogen Bond \\
\hline & & :UNK0:C13 - A:ILE330 & 4.14 & Hydrophobic & Alkyl \\
\hline & & :UNK0:C13 - B:LEU153 & 4.26 & Hydrophobic & Alkyl \\
\hline & & B:TRP144 - :UNK0:C15 & 5.32 & Hydrophobic & Pi-Alkyl \\
\hline 5. Isoborneol- LOX & -153.0 & :UNK0:C10 - A:ILE330 & 4.76 & Hydrophobic & Alkyl \\
\hline
\end{tabular}

\section{CONCLUSION}

The phytosterol compounds containing $C$. longa and $C$. citratus might have potential antiinflammatory effects through lipoxygenase inhibitor activities.

\section{REFERENCES}

[1] Viktorová J, Stupák M, Řehořová K, Dobiasová S, Hoang L, Hajšlová J, et al. 2020. Lemon grass essential oil does not modulate cancer cells multidrug resistance by citral-its dominant and strongly antimicrobial compound. Foods.9(5).

[2] Mohamed Hanaa AR, Sallam YI, El-Leithy AS, Aly SE. 2012. Lemongrass (Cymbopogon citratus) essential oil as affected by drying methods. Ann Agric Sci.57(2):113-6.
[3] Bayala B, Coulibaly AY, Djigma FW, Nagalo BM, Baron S, Figueredo G, et al. 2020. Chemical composition, antioxidant, anti-inflammatory and antiproliferative activities of the essential oil of Cymbopogon nardus, a plant used in traditional medicine. Biomol Concepts. 11(1):86-96.

[4] Bare Y. 2021. Analisis Senyawa Fitosterol Cymbopogon citratus dan Curcuma longa sebagai Antialzheimer. Biopendix J Biol Pendidik Dan Terap.7(2):53-159.

[5] Costa CARA, Bidinotto LT, Takahira RK, Salvadori DMF, Barbisan LF, Costa M. 2011. Cholesterol reduction and lack of genotoxic or toxic effects in mice after repeated 21-day oral intake of lemongrass (Cymbopogon citratus) essential oil. Food Chem Toxicol. 49(9):2268-72.

[6] 6. Boukhatem MN, Ferhat MA, Kameli A, Saidi F, Kebir HT. Lemon grass 
(Cymbopogon citratus) essential oil as a potent anti-inflammatory and antifungal drugs. Libyan J Med. 2014;9(25431):1-10.

[7] Baird L, Yamamoto M. 2020. The Molecular Mechanism Regulating the KEAP1-NRF2 Pathway. Mol Cell Biol. 40(13):1-23.

[8] Avoseh O, Oyedeji O, Rungqu P, NkehChungag B, Oyedeji A. 2015. Cymbopogon species; ethnopharmacology, phytochemistry and the pharmacological importance. Molecules. 20(5):7438-53.

[9] Chartoumpekis D, Kensler T. 2013. New Player on An Old Field; the Keap1/Nrf2 Pathway as a Target for Treatment of Type 2 Diabetes and Metabolic Syndrome. Curr Diabetes Rev. 9(2):137-45.

[10] Gbenou JD, Ahounou JF, Akakpo HB, Laleye A, Yayi E, Gbaguidi F, et al. 2013. Phytochemical composition of Cymbopogon citratus and Eucalyptus citriodora essential oils and their anti-inflammatory and analgesic properties on Wistar rats. Mol Biol Rep.;40(2):1127-34.

[11] Kim S, Kim M, Kang M, Lee HHL, Cho CH, Choi I, et al. 2021. Antioxidant Effects of Turmeric Leaf Extract against Hydrogen Peroxide-Induced Oxidative Stress In Vitro in Vero Cells and In Vivo in Zebrafish. Antioxidants.10(112):1-14.

[12] Amalraj A, Pius A, Gopi S, Gopi S. 2017. Biological activities of curcuminoids, other biomolecules from turmeric and their derivatives - A review. J Tradit Complement Med. 7(2):205-33.

[13] Tanvir EM, Hossen MS, Hossain MF, Afroz R, Gan SH, Khalil MI, et al. 2017. Antioxidant properties of popular turmeric (Curcuma longa) varieties from Bangladesh. J Food Qual.;2017.

[14] Umar NM, ivam TP, Aminu N, Toh SM. 2020. Phytochemical and pharmacological properties of Curcuma aromatica Salisb (wild turmeric). $J$ Appl Pharm Sci.10(10):180--194.

[15] Bare Y, Marhendra A, Sasase T, Fatchiyah F. 2018. Differential Expression of IL-10 Gene and Protein in Target Tissues of Rattus Norvegicus Strain Wistar Model Type 2 Diabetes Mellitus (T2DM). Acta Inform Medica. 26(2):87-92.

[16] Andriyono RI. 2019. Kaempferia galanga L. sebagai Anti-Inflamasi dan Analgetik. $J$ Kesehat. 30;10(3):495.

[17] Mueller M, Hobiger S, Jungbauer A. 2010. Anti-inflammatory activity of extracts from fruits, herbs and spices. Food Chem.122:987-96.

[18] Al-u'datt D, Allen BG, Nattel S. 2019. Role of the lysyl oxidase enzyme family in cardiac function and disease. Cardiovasc Res. 20; 176.

[19] Putri CRH. 2017. The Potency and Use of Tamarindus indica on Various Therapies. $J$ Ilm Kedokt Wijaya Kusuma. 12;3(2):40.

[20] Schröter D, Neugart S, Schreiner M, Grune T, Rohn S, Ott C. 2019. Amaranth's 2Caffeoylisocitric Acid-An AntiInflammatory Caffeic Acid Derivative That Impairs NF- $\kappa$ B Signaling in LPS-Challenged RAW 264.7 Macrophages. Nutrients. 7;11(3):571.

[21] Chaudhury A, Duvoor C, Reddy Dendi VS, Kraleti S, Chada A, Ravilla R, et al. 2017. Clinical Review of Antidiabetic Drugs: Implications for Type 2 Diabetes Mellitus Management. Front Endocrinol. 2017;8.

[22] Rao CV, Janakiram NB, Mohammed A. 2012. Lipoxygenase and Cyclooxygenase Pathways and Colorectal Cancer Prevention. Curr Colorectal Cancer Rep. 8(4):316-24.

[23] Pihlaja R, Haaparanta-Solin M, Rinne JO. 2017. The Anti-Inflammatory Effects of Lipoxygenase and Cyclo-Oxygenase Inhibitors in Inflammation-Induced Human Fetal Glia Cells and the $A \beta$ Degradation Capacity of Human Fetal Astrocytes in an Ex vivo Assay. Front Neurosci. 30;11:299.

[24] Wisastra R, Dekker F. 2014. Inflammation, Cancer and Oxidative Lipoxygenase Activity are Intimately Linked. Cancers. 17;6(3):1500-21.

[25] Bare Y, Kuki AD, Rophi AH, Candrakirana G. 2019. Prediksi Asam Kuinat Sebagai AntiInflamasi Terhadap COX-2 Secara Virtual Virtual Prediction of Quinic Acid As AntiInflammation of COX-2. Biota J Ilmu-Ilmu Hayati. 4(3):124-9.

[26] Zhou W, Yan H, Hao Q. 2012. Analysis of surface structures of hydrogen bonding in protein-ligand interactions using the alpha shape model. Chem Phys Lett.545:125-131.

[27] Bare Y, Krisnamurti GC, Elizabeth A, Rachmad YT, Sari DRT, Lorenza MaRW. 2019. The potential role of caffeic acid in coffee as cyclooxygenase-2 (COX-2) inhibitor: in silico study. Biointerface Res Appl Chem. 15;9(5):4424-7.

[28] Bare Y, S M, Tiring SSND, Sari DRT, Maulidi A. 2020. Virtual Screening: Prediksi potensi 8-shogaol terhadap c-Jun N-Terminal Kinase (JNK). J Penelit Dan Pengkaj Ilmu Pendidik E-Saintika. 5;4(1):1-6.

[29] Bare Y, Helvina M, Krisnamurti GC, S M. 2020. The Potential Role of 6-gingerol and 6shogaol as ACE Inhibitors in Silico Study. Biog J Ilm Biol. 30;8(2):210.

[30] Kapinova A, Stefanicka P, Kubatka P, Zubor P, Uramova S, Kello M, et al. 2017. Are plant-based functional foods better choice 
against cancer than single phytochemicals? A critical review of current breast cancer research. Biomed Pharmacother. 96(11):1465-77.

[31] DRT Sari, JRK Cairns, A Safitri, F Fatchiyah. 2019. Virtual Prediction of the Delphinidin-3-O-glucoside and Peonidin-3$\mathrm{O}$-glucoside as Anti-inflammatory of TNF- $\alpha$ Signaling. Acta Informatica Medica, 27 (3), 152-157.

[32] Van Breda SGJ, Briedé JJ, de Kok TMCM. 2019. Improved preventive effects of combined bioactive compounds present in different blueberry varieties as compared to single phytochemicals. Nutrients.11(1).

[33] DRT Sari, A Safitri, JRK Cairns, F Fatchiyah. 2020. Anti-apoptotic activity of anthocyanins has potential to inhibit caspase3 signaling. Journal of Tropical Life Science, 10 (1), 15-25.

[34] Bare Y, Sari DR, Rachmad YT, Tiring SSND, Rophi AH, Nugraha FAD. 2019. Prediction Potential Chlorogenic Acid As Inhibitor Ace (In Silico Study). Bioscience. Oct 31;3(2):197. 